\title{
Werken op een corona-afdeling
}

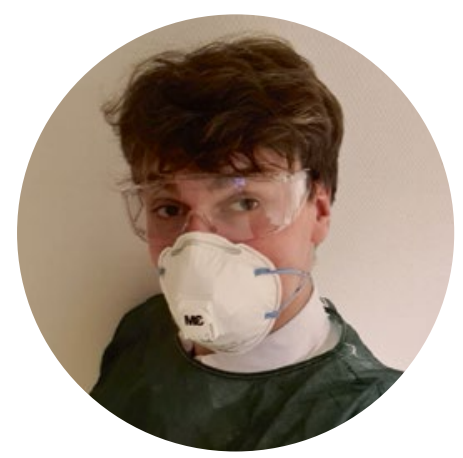

\section{Wanneer zzp-verzorgende ig Julian Hooikaas zich opgeeft bij een meldpunt om bij te springen tijdens de coronacrisis, wordt hij de volgende dag direct gebeld om aan de slag te gaan op een afdeling met COVID-19-patiënten. Hoe ervaart hij dit werk? 'Je zou hiervan PTSS kunnen oplopen.'}

TEKST: RHIJJA JANSEN FOTO: VAN ASSENDELFT FOTOGRAFIE

\section{Waarom gaf je je op bij het meldpunt?}

'Ik wist dat er zorgmedewerkers nodig waren en ik wil liever niet dat gepensioneerde verzorgenden dit gaan doen. Het lijkt me risicovol om als 60-plusser aan het bed van een coronapatiënt te staan. Mijn moeder zegt altijd: "Het oude vlees moet eerst op", maar in dit geval denk ik: het jonge vlees moet eerst op. Daarnaast geeft dit een kick: nu kunnen we laten zien dat we broodnodig zijn. Of je wilt of niet, je kunt niet zonder ons, de zorgmedewerkers.'

\section{Waar kwam je terecht?}

'Ze vroegen of ik wilde bijspringen in Brabant. Ik woon zelf in Rotterdam en de zorgtekorten in Brabant zijn zo hoog, dat ze mensen van boven de rivieren zoeken. Ik draai voornamelijk nachtdiensten op een verpleegafdeling met COVID-19-patiënten.'

\section{Wat zijn je taken?}

'Mensen draaien, vitale functies in de gaten houden en kijken of ik iets kan doen tegen de koorts. Bijvoorbeeld met voorgeschreven paracetamol of een koeldeken. Als ik zie dat iemand heel snel achteruitgaat, moet ik hem insturen naar het ziekenhuis. Dat heb ik de afgelopen drie nachtdiensten een keer gedaan, en die patiënt is ook opgenomen.'

\section{Wat waren je verwachtingen van het werk?}

'Ik dacht van tevoren: het valt wel mee. Ik wist dat de patiënten een hoge zorgvraag hebben, maar dat hebben pg-cliënten ook. Nu moet je voor pg-cliënten ook veel doen, maar ik merkte direct: COVID-19-patiënten hebben véél meer hulp nodig. Ze kunnen nog geen stap zetten, of zijn al buiten adem. Alsof ze zwaar COPD-patiënt zijn.'

\section{Hoe ervaar je dit werk?}

'Het is ontzettend indrukwekkend. Hiervoor dacht ik dat alleen oudere mensen hieraan doodgaan. Die ene jonge persoon zou wel een uitzondering zijn. Nu weet ik: ook jonge, vitale mensen die niks hadden, kunnen ongelofelijk getroffen worden door deze ziekte. De meeste patiënten zijn boven de vijftig, maar er zijn ook een paar dertigers. Al mijn collega's zeggen ook: het is ongelofelijk eng. En dat heb ik zelf ook ervaren.'

\section{Wat is eng?}

'Dat deze ziekte zo onvoorspelbaar is. Patiënten zijn ook echt bang, er is een gespannen sfeer. Normaal werk ik in de palliatieve zorg, en daar hangt meestal een serene sfeer, omdat de cliënt er vrede mee heeft dat hij zal sterven. Maar deze patiënten zijn overvallen door het coronavirus en denken: wat gebeurt er met mij? Ze willen leven. Als verzorgende voel ik me machteloos, omdat het heel moeilijk te voorspellen is hoe het afloopt met een patiënt. Als je met het coronavirus besmet wordt, lijken er drie scenario's te zijn: milde klachten, hevige klachten of doodgaan.' 


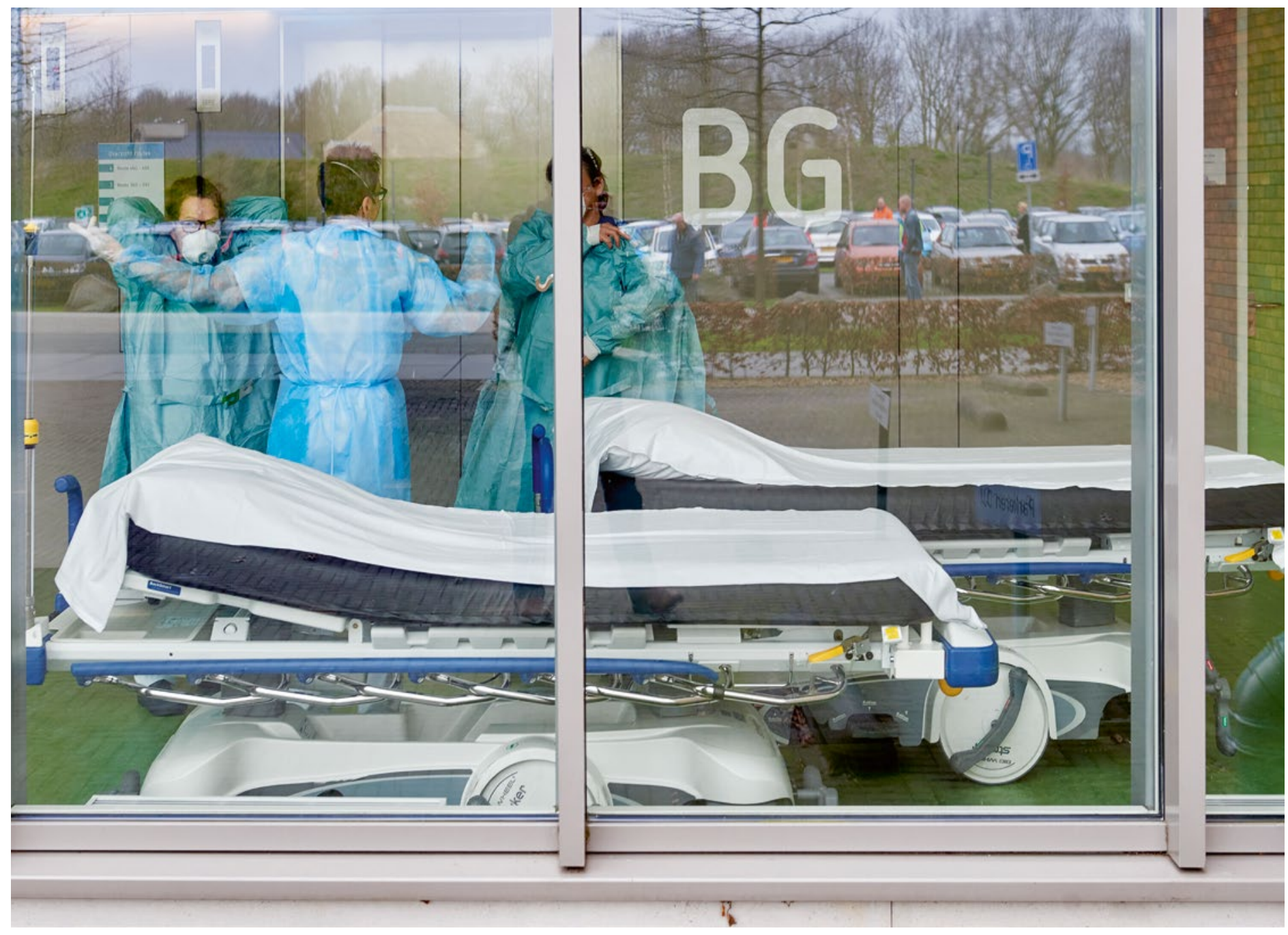

\section{Wat doet dat met jou persoonlijk?}

'Het hakt erin. Ik heb een paar keer na mijn dienst vloekend in de auto gezeten, moest tien minuten tot rust komen voordat ik in staat was om te rijden. Gehuild heb ik ook, maar dat doen we allemaal in mijn team. Huilen, lachen, hele harde grappen maken. Ik heb echt een topteam, waarin we veel steun aan elkaar hebben. De sfeer is top. Je wordt snel hecht met elkaar als je samen zoiets bizars meemaakt. Er staan ook studenten verpleegkunde aan het bed. Ik hoop dat toekomstige studenten dit nooit hoeven mee te maken. Dit blijft je je leven lang bij. Het zal me niks verbazen als veel zorgverleners straks de GGZ platlopen. Je zou hier PTSS van kunnen oplopen.'

\section{Hoe is het om in zo'n beschermend pak patiënten te verplegen?}

'Warm. Ik zweet normaal al veel, maar in zo'n pak zweet ik me echt de tieftandjes. Alles is van plastic: je pak, mondmasker, bril. Niks ademt. Het is ook moeilijk om zo ingepakt contact te maken met patiënten. Sommigen horen me niet goed. Ik heb nu mijn mobiele telefoon in huishoudfolie verpakt, zodat ik hier dingen op kan schrijven en kan laten lezen aan de patiënt. Dat gaat sneller dan wanneer ik mijn boodschap door twee maskers heen schreeuw.'

\section{Ben je bang zelf besmet te worden?}

'Nee. Mijn moeder vindt het wel vreselijk spannend. Ik heb ook niet een geweldige gezondheid: een hartritmestoornis en van jongs af aan slechte longen. Toch denk ik dat het besmettingsgevaar hier in mijn beschermingspak net zo groot is als wanneer je onbeschermd in de supermarkt loopt. Ik ben er vrij nuchter in.'

\section{Kun je dit werk collega-verzorgenden aanraden?}

'Het hangt ervan af. Als je elk virus oppakt, zou ik niet op een afdeling als deze gaan werken. En je moet mentaal tegen een stootje kunnen. Ik heb al gedacht: waar ben ik aan begonnen? Maar wil zeker niet stoppen. Ik stop pas als dit voorbij is, al heb ik geen idee hoelang het nog duurt. De piek wordt in mei verwacht. Het is heftig, maar geeft ook ongelofelijk veel voldoening. Toen ik iemand bij ontslag naar buiten zag lopen, was ik blij. Ja, dacht ik.

Daar doe ik het voor.'

Het interview is eind maart afgenomen 